\title{
LACK OF INTEREST IN SCHOOL SCIENCE AMONG NON-SCIENCE STUDENTS AT THE SENIOR HIGH SCHOOL LEVEL
}

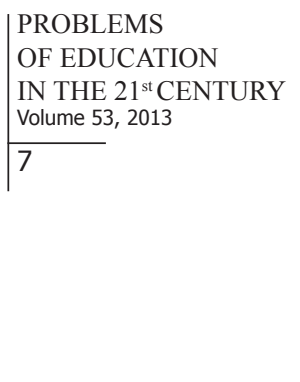

\author{
Kenneth Adu-Gyamfi \\ Mampong Technical College of Education, Ghana \\ E-mail: dondonsinco@yahoo.com
}

\begin{abstract}
This study investigated the factors that contribute to the non-science students' lack of interest in school science through the use of a 27-item questionnaire. This assisted in comparing the male and female non-science students' lack of interest in school science. There were 259 male and female students from three senior high schools in three District Assemblies of the Ashanti Region of Ghana who participated in the study. Quantitative data were collected from the 259 students through a cross-sectional survey. The research questions were answered with mean, standard deviation, percentage, boxplot, and independentsamples t-test. The results of the study have shown that the factors that contribute to students' lack of interest in school science include as higher demands of students' time in learning science, less practical nature of science teaching and learning, failure of science students with larger aggregate from high school to gain admission into tertiary institutions, too broad nature of science content, lack of sponsorship for science students, school science as difficult subject compared to others, and teaching of science is a transmission of knowledge from science teachers or textbooks to students. The results of the study have further shown that there was a statistical significant difference between the mean scores of male and female non-science students' lack of interest in school science. Science teachers are therefore encouraged to adopt strategies that could encourage students to develop and show interest in science related subjects and courses.
\end{abstract}

Key words: factors; lack of interest; male and female; non-science students; school science.

\section{Introduction}

The concept, interest has been an area of concern to psychologists particularly that of students' interest. From Renninger and Hidi (2011), interest is the students' psychological state which develops over a period of time as the students interact with the environment. Interest as seen by Thoman, Sansone, Fraughton, and Pasupathi $(2012$, p. 2) is "a dynamic state that arises through an ongoing transaction among goals, context, and actions". Hidi and Renninger (2006) explained that interest is predisposition of students to spend time on topics, concepts, ideas, or activities. According to Thoman, Sansone, Fraughton, and Pasupathi (2012), researchers have found out that students' interest in a subject or course of study have positive influence on their learning and even the choice of subjects/courses and careers they make as students. The level of students' interest in a particular subject/course or career has been found to vary and that students' lack of interest in a course or career could be nurtured with supports to become a future interest (Renninger \& Hidi, 2011). This is because a number of factors come onboard when it comes to students' interest. The reveal of the literature by Thoman, Sansone, Fraughton, and Pasupathi (2012) identified factors such as a learning environment, academic performance, parents, peers, and teachers as having the potential of influencing students' interest.

In this study interest was considered as cognitive and affective state of the students involved in the study with respect to their experience with the environment that supports the teaching and learning of school science. The cognitive and affective states of the students were looked at in relation to experience because the targeted population for the study was one that 
Kenneth ADU-GYAMFI. Lack of Interest in School Science among Non-science Students at the Senior High School Level

PROBLEMS

OF EDUCATION

IN THE $21^{\text {st }}$ CENTURY

Volume 53,2013

8

has once had the feel of school science and was provided with an opportunity to chose it as a field of study but opted out.

Today's scientific and technological advancement has necessitated the need for most countries in the world to invest in school science and technology in order to provide the required manpower in these areas for their economies. Ghana as one of such countries having seen the strength of science and technology in today's world economy proposed that the future direction of education in Ghana as seen in the 2004 Education Reforms was to train the citizens of school-going age to be enterprising and adaptable to the fast-changing demands of the word propelled by modern science and technology (Ministry of Education, Youth, and Sports [MEYS], 2004). According to Wells, Sanchez, and Attridge (n.d.), the U. S. has realised that the American education system must provide an expanding and highly talented pool of science, technology, engineering, and mathematics (STEM) professionals. To be able to do this, the Business-Higher Education Forum launched a multi-year initiative to identify the number of problems that exist in U.S. today's education system. The problems identified were low student participation in STEM, declining achievement in STEM subjects to other countries, the shortage of qualified STEM teachers, and the lack of women participation in STEM disciplines (Wells, Sanchez, \& Attridge, n.d.). The shortage of qualified STEM teachers could be that students are not taking to STEM-related programmes in schools and colleges, and that, students who take to the subjects and courses related to STEM do not graduate from schools and colleges to practice their profession.

From Fensham (2006), the studies conducted by Goodrum, Hackling, and Rennie in the year 2001 in Australia and by TIMMS in the year 2003 with secondary school students have revealed that most students did not agree to the statement that school science "was relevant to my present or future, or helps me make decisions about my health, and that $62.0 \%$ and $65.0 \%$ of females and males in year four like science, but by year eight only $26.0 \%$ and $33.0 \%$ did so" (p. 71). Another area that could be of interest to the problems of science education in the schools and colleges in today's world is the mode of admission. Universities and for that matter tertiary institutions in the world today give many more avenues and opportunities to students who choose other courses without any strings attached as compared to science-related faculties (Fensham, 2006). This could be the reason why some countries are losing students who could study school science to become professionals in STEM to other areas of study.

Christidou (2011) asserted that the science textbooks and mass media inevitably influence the interest of students in school science. The study conducted by Semala (2010) with Ethiopian university students showed that students' low interest in science-related subjects or courses are as a result of the science textbooks used as well as teachers and their teaching practices. It has once been recommended that the methods and techniques of teaching of school science should be carefully selected to reflect students' interest and involvement in school science (Christidou, 2006). This could be that the instructional methods adopted by teachers in the teaching of school science could influence students' attitudes positively or otherwise towards science, hence the need to be tactful in the selection of instructional methods for the teaching of school science.

From Christidou (2011), the lack of relevance of the science curriculum affects the interest of students negatively in science education. He therefore recommended that the science curriculum should be improved to enhance students' interest in school science. The nature of science is such that there is a lot to study at any point in time, and thus science curricula for the schools and colleges are packed at each level of study to cater for its characteristic broad nature. Hence, according to Christidou (2011), factors such as the following should be considered in preparation of science curricula for the schools and colleges. This is because such factors will enhance the interest of students in science. The factors to be considered as given by Christidou (2011) were: 
The combined investigation and conceptions about students' attitudes, interests, and conceptions about science, their differentiations according to the different identities students' construct, their evolution with age as well as the contribution of school science, teachers, and popular information sources to their formation can constitute an important first step for developing appropriate teaching and training science programmes for students and teachers (p. 151).

Investigations into students' voice, school science and teachers, and popular science helped to establish relationships between them. This is because the relationships between students' voice, school science and teachers, and popular science influenced the interest of students in science-related studies and careers (Christidou, 2011). However, the views of scientists and science educators are said to be the only important views when it comes to issues in science education. This is because students' voices are absent in determining what to learn, value, and use in everyday life (Osborne \& Collins, 2001).

Fensham (2006) explained that there are a lot of job opportunities to graduates of other fields than the graduates from the science sector. This is because the science graduates lack the requisite skills in science and technology in the modern knowledge society. This could also be related to the lack of knowledge of students about career prospects in science education. The Organisation of Economic Co-operation and Development [OECD] (2006) found that career paths taken by students are commonly based upon their interest in a particular field and on the perception of job opportunities in that field. Osborne and Collins (2001) revealed that science has a marketing problem. In the sense that the main premium students place on school science was its instrumental one but not its intrinsic interest. This is because some students thought that they do not need scientific knowledge to be employed as hairdresser, banker, artist, or lawyer. Hence, from OECD (2006), "provision of accurate information is an important aspect of any policy to increase the attractiveness of science and technology studies and careers" (p. 2). Information on scientists and the works of scientists could be made available to students and the general public through the mass media to help students and the general public to appreciate the value of science in today's world. For instance, a student by the name Lucy said:

It's really important for me to learn science to keep in line with everything else, because, if you switch on the TV, they're always talking about things that they've discovered and new ways they can do things. To understand what they're talking about you've got to know about science (Osborne \& Collins, 2001, p. 447).

From OECD $(2006 ; 2008)$, there has been a rise in the number of students in upper secondary and tertiary education who pursue school science and science-related programmes. However, this number was seen to be on the lower side with respect to the overall student population in tertiary and secondary schools in Australia and across the OECD and beyond (Fensham, 2006; OECD, 2006; 2008). In Ghana the 2004 Education Reforms brought to the fore four years' period of Senior High School (SHS) education, where all students study Mathematics, Computer Science, General Science, Social Studies, and English Language in the first two years (MEYS, 2004). The SHS students in Ghana having studied these compulsory subjects for a year were made to select 'elective' subjects which symbolise the field of study of the students. The survey of 10 SHSs in five Districts Assemblies of the Ashanti Region revealed that the number of students entering each school each year has increased since 2007/2008 academic year where Ghana's 2004 Educational Reforms was implemented. However, the percentage of students in the fields of study that are science related with respect to the other subjects was calculated approximately as $30.8 \%$. Could the decline in the number of students who study school science at all levels of education be the perceived difficult nature of school science with respect to other subjects and courses (Fensham, 2006)?

Students' difficulty in learning science could be attributed to the perceived lack of rele- 
Kenneth ADU-GYAMFI. Lack of Interest in School Science among Non-science Students at the Senior High School Level

PROBLEMS

OF EDUCATION

IN THE $21^{\text {st }}$ CENTURY

Volume 53, 2013

10

vance of science topics such as learning of chemical equations and bonding for continuing education and career aspirations. Another aspect of the difficulty has got to do with the language of science, which was said to be composed of unfamiliar words (Osborne \& Collins, 2001). From Wells, Sanchez, and Attridge (n.d.), students who were proficient and advanced in Mathematics were found to be interested in STEM-related subjects or courses. This is because students appreciated that the difficult nature of school science in the areas of Physics and Chemistry has its roots in Mathematics (Osborne \& Collins, 2001). Hence, a good knowledge of Mathematics is a prerequisite for understanding scientific concepts. This perceived Mathematics inclined school science affects the number of students who take to STEM at another level of education (Wells, Sanchez, and Attridge, n.d.).

Christidou (2011) recommended that for the interest of students to be built-up in school science, science should be promoted as an interesting and attractive activity; all voices should be heard and valued, and students should be provided with role models, especially females. An interpersonal factor that received the highest mean score rating from 2861 secondary school students was role model. The students agreed that role model influenced the career choices and courses (Ocansey, 2009) and that female students are likely to take science to higher levels of learning when they are given the opportunity to interact with female scientists frequently (Mensah, 2007).

The practice of science teaching and learning should be adopted in such a way that school science could equally be appropriate for male and female students. From Christidou (2006), when school science curricula are prepared to suit the interest of female students, such curricula could be said to favour their male counterparts. This is because the topics and fields of study preferred by female students are equally attracted to male students. The work of Osborne and Collins (2001) showed that boys are currently showing interest in topics in Biology, which continuously retains its traditional appeal with girls. This is an indication that if school science topics are liked by female students, their male counterparts will as well show interest in such scientific topics.

In Ghana, the work of Mensah (2007) on gender and developmental differences has revealed that there is a positive correlation among attitudes of female students in junior high schools (JHS) one and three towards school science. Such a positive attitude shown by the JHS students should have positively influenced the number of students entering into science-related subjects at the SHS level from the JHS. But this was not the case as there was low number of female students in science-related subjects. This is because the survey of the 10 SHSs in the five Districts Assemblies of the Ashanti Region in the February 2012 showed a less than 30.0\% of female representation of students in the science related programmes as compared to the overall female student population in the schools. Female low preference for school science as compared to other subjects and courses could be attributed to negative pressures and external expectations (OECD, 2006). It was therefore important to investigate the factors that contribute to the declined number and lack of interest of students in school science.

\section{Purpose of the Study}

The purpose of the study was therefore to investigate the factors that contribute to the lack of interest in school science among non-students (who after the first year of the SHS education opted not to offer science-related programmes at the SHS level). This assisted in comparing the lack of interest of male and female non-science students in school science. This was conducted using a 27-item questionnaire. The purpose of the study was determined through the following research questions:

1. What factors contribute to the lack of interest in school science among non-science students at the SHS level?

2. To what extent is female non-students' lack of interest in science different from that of their male counterparts? 


\section{Methodology of Research}

\section{Research Design}

The study employed quantitative methods (Cohen, Manion, \& Morrison, 2005; Creswell, 1994) to investigate the factors that contribute to the lack of interest in school science among non-science students at the SHS level. With the help of a cross-sectional survey, quantitative data on factors that contribute to the lack of interest in school science among non-science students were collected. The first stage of the survey was the construction of a five-section questionnaire on factors that contribute to the lack of interest of non-science students in school science. After the construction of the instrument, it was pilot-test with 22 SHS 3 non-science students from Central Region of Ghana at the second stage of the survey. The purpose was to establish the reliability of the instrument. At the third stage of the survey, the questionnaire was administered to SHS 3 non-science students selected from three District Assemblies of the Ashanti Region of Ghana. The questionnaire helped to quantify the students' views on the factors that contribute to the lack of interest in school science among the non-science students.

\section{Sample}

The students involved in the study were SHS 3 non-science students in the 2011/2012 academic year. The non-science students were the students who did not offer Biology, Chemistry or Physics as one of their elective subjects. These students were targeted for the study because they were the students that the field of science lost to other fields of study, and hence their views about science were important to inform policy formation to attract students to study school science. The students were selected respectively from three schools in Mampong Municipality, Sekyere Central, and Sekyere South Districts of the Ashanti Region of Ghana. A sample size of 259 non-science students consisting of $44.8 \%$ of male and $55.2 \%$ of female students were randomly selected to participate in the study. The 259 students were those who responded to the questionnaire and returned them during the period of data collection.

\section{Instrument}

The main instrument used in this study was a five point Likert scale questionnaire consisting of 27 items. The questionnaire was used because the survey employed this questionnaire which helped to use the same items to collect the needed information from the 259 non-students involved in the study (Cohen, Manion, \& Morrison, 2005). Though psychologists such as Renninger and Hidi (2011) questioned the reliability of a single instrument for investigating the interest of students in any field of research, however the 27-item questionnaire used for the current study was carefully constructed and used to eliminate such a doubt. The items were carefully constructed because they were constructed based partly on the literature reviewed and on an interview with some non-science students in some SHSs outside the schools in the District Assemblies in the Ashanti Region of Ghana which were involved in the study. The purpose of the interview with the students was to have a first-hand experience of the views of students on teaching and learning of science and to construct quality and valid items to be used on the questionnaire. The students were interviewed on:

1. What students like about school science?

2. What students dislike about school science?

3. The relevance of school science to the lives of the students.

4. The challenges the students are faced with in learning school science. 
PROBLEMS

OF EDUCATION

IN THE $21^{\text {st }}$ CENTURY

Volume 53, 2013

12

5. The students' perspective of the way forward for the teaching and learning of school science at the SHS level.

With respect to the responses of the students who were interviewed and the issues raised in the literature, a 33-item questionnaire consisting of five sections was constructed. The sections of the questionnaire were social (interactions of the students with other peoples), support (facilities provided by institutions, governments, and NGOs to assist students to learn school science), future prospects (expectation of the students about the study of school science), content and pedagogy (nature and teaching of scientific knowledge), and performance (what students can accomplish in school science and its related subjects).

The instrument was pilot-tested with 22 non-science students (of similar characteristics to the students involved in the study) from Central Region of Ghana. The items on the questionnaire were therefore subjected to item analysis which led to the deletion of six items that were measuring different construct in relation to the other items. The Cronbach's alpha coefficient of reliability was calculated as 0.8 after the item analysis. This Cronbach's alpha value gave an indication that the questionnaire was reliable, and hence its usage to investigate such an all important area in science education at the high school level in Ghana.

\section{Analysis}

The results of the study were analysed using both descriptive and inferential statistics. The research question 1 was answered using percentages, means, and standard deviations. The mean score and standard deviation on a five point Likert scale were calculated for each item on the questionnaire. The five point Likert scale was coded as strongly agree; 4, agree; 3, disagree; 2 , strongly disagree; 1 , and undecided; 0 . Any 'undecided' response was treated as if the student or students had failed to respond to the item. This in effect led to the reduction of the total number of students who responded to each item, and the five point Likert scale was then used as a four point Likert scale as strongly agree; 4, agree; 3, disagree; 2, and strongly disagree; 1. In analysing the items on the Likert scale, a mean score of 2.5 and above was an indication of agree statement and a mean score of 2.4 and below was an indication of a disagreement.

The boxplot and independent-samples t-test were used to answer the research question 2. The boxplot was used to show the difference between male and female non-science students' lack of interest in school science. The independent-samples t-test was used to test for the statistical significance of the difference between male and female non-science students' lack of interest in school science in order to show the extent of the difference. The use of the independent-samples t-test was because when the normality of the scores was tested using the Kolmogorov-Smirnov test, the distribution was found to be normal as the significance level was calculated as 0.20 for both male and female students. It could be seen that the calculated significance level of 0.20 was more than the assumed significance value of 0.05 (Pallant, 2005). Hence the distribution of the scores from the questionnaire could be said to be normal and that the independent samples t-test was the appropriate parametric test to test the significance of the difference between two independent variables (male and female) on a continues variable.

\section{Results of Research}

\section{Factors that Contribute to Non-science Students'Lack of Interest in School Science}

The research question 1 sought to find out the factors that contribute to the lack of interest in school science among SHS non-science students. To be able to do this, 259 SHS 3 nonscience students were given a 27-item questionnaire consisting of sections on social, support, future prospects, content and pedagogy, and performance related factors to respond to. The results in Table 1 present the mean rank of the responses of the students on the factors that contribute to the non-science students' lack of interest in school science. 
Table 1. Mean Rank of the Factors that contribute to Non-Science Students' Lack of Interest in School Science $(\mathbf{N}=259)$.

\begin{tabular}{|c|c|c|c|c|c|}
\hline Statement & $\mathrm{A} / \%$ & $\mathrm{D} / \%$ & $\mathrm{n}$ & Mean & SD \\
\hline \multicolumn{6}{|l|}{ Science demands a lot of student's time of learning to } \\
\hline If teaching and learning of science could be more & 00.0 & 0.0 & $2+1$ & 0.7 & 0.1 \\
\hline practical than it is now, I would have studied science & 85.3 & 10.0 & 247 & 3.4 & 0.7 \\
\hline $\begin{array}{l}\text { If I will be given an automatic admission to any tertiary } \\
\text { institution when I passed all subjects with a larger }\end{array}$ & & & & & \\
\hline aggregate & 80.7 & 11.9 & 240 & 3.3 & 0.7 \\
\hline The content of science is too broad & 82.3 & 13.6 & 248 & 3.3 & 0.8 \\
\hline \multicolumn{6}{|l|}{ I will study science if I will be sponsored to study science } \\
\hline to the university level & 72.2 & 20.5 & 244 & 3.2 & 0.9 \\
\hline $\begin{array}{l}\text { Science is difficult to learn in comparison with other } \\
\text { subjects }\end{array}$ & 74.2 & 20.0 & 244 & 3.0 & 1.0 \\
\hline \multicolumn{6}{|l|}{ My lack of interest in science was not due to the } \\
\hline the study of science & 72.9 & 24.7 & 253 & 3.1 & 1.1 \\
\hline \multicolumn{5}{|l|}{ I see science as a transmission of knowledge from teacher } & 0.9 \\
\hline \multicolumn{5}{|l|}{ I will study science if I will be guaranteed job with higher } & 0.9 \\
\hline salaries & 62.5 & 30.9 & 242 & 2.9 & 1.0 \\
\hline $\begin{array}{l}\text { My lack of interest in science was influenced by my weak } \\
\text { performance in mathematics }\end{array}$ & 61.8 & 30.1 & 238 & 2.9 & 1.0 \\
\hline \multicolumn{6}{|l|}{ I would have studied science if my science teachers } \\
\hline $\begin{array}{l}\text { encouraged me to } \\
\text { My lack of interest in science was due to the fact that I }\end{array}$ & 61.0 & 32.5 & 242 & 2.8 & 0.9 \\
\hline used to score low marks in science & 58.6 & 32.4 & 236 & 2.8 & 0.9 \\
\hline \multicolumn{6}{|l|}{ I will study science if I will meet my future career } \\
\hline $\begin{array}{l}\text { I would have studied science if science is promoted like } \\
\text { sports or politics in Ghanaian mass media (for example, }\end{array}$ & & & & & \\
\hline FM/TV) & 53.3 & 38.2 & 237 & 2.7 & 1.0 \\
\hline \multicolumn{6}{|l|}{ Science students most at times fail to quality for } \\
\hline \multicolumn{6}{|l|}{ I would have studied science if my parents/guardian } \\
\hline encouraged me to study science & 51.0 & 35.2 & 223 & 2.7 & 1.0 \\
\hline In Ghana most science students end up becoming teachers & 51.0 & 40.1 & 236 & 2.6 & 1.0 \\
\hline \multicolumn{6}{|l|}{ Our class size is large and that science cannot be studied } \\
\hline \multicolumn{6}{|l|}{ I would have studied science if my local language was } \\
\hline used in teaching it & 41.8 & 49.8 & 237 & 2.4 & 1.0 \\
\hline I would have studied science if people from my & 322 & 552 & 220 & 23 & \\
\hline \multicolumn{5}{|l|}{$\begin{array}{l}\text { I would have studied science if Physics and Chemistry } \\
\text { were made elective subjects for all students at the third }\end{array}$} & 1.0 \\
\hline year of the four-year secondary education & 29.7 & 59.4 & 231 & 2.2 & 1.0 \\
\hline $\begin{array}{l}\text { I see science as content of knowledge that is irrelevant } \\
\text { and boring to our lives }\end{array}$ & 28.9 & 64.9 & 243 & 2.1 & 1.0 \\
\hline $\begin{array}{l}\text { I would have studied science if my voice was heard and } \\
\text { valued in science lessons }\end{array}$ & 22.8 & 65.6 & 229 & 2.0 & 0.9 \\
\hline The subject science is for intellectually gifted students & 20.8 & 72.9 & 243 & 1.9 & 0.9 \\
\hline $\begin{array}{l}\text { I would have studied science if the topics are attracted to } \\
\text { the girls }\end{array}$ & 13.1 & 82.3 & 247 & 1.7 & 0.8 \\
\hline $\begin{array}{l}\text { I would have studied science if my closest friend also } \\
\text { studied science }\end{array}$ & 8.5 & 88.1 & 250 & 1.6 & 0.8 \\
\hline
\end{tabular}


Kenneth ADU-GYAMFI. Lack of Interest in School Science among Non-science Students at the Senior High School Level

\author{
PROBLEMS \\ OF EDUCATION \\ IN THE $21^{\text {st }}$ CENTURY \\ Volume 53,2013 \\ 14 Where $\mathrm{N}=$ the total number of students who participated in the study \\ $\mathrm{n}=$ the number of students who indicated agreed or disagreed to each statement \\ $\mathrm{A} / \%=$ the percentage of students who agreed to each statement \\ $\mathrm{D} / \%=$ the percentage of students who disagreed to each statement
}

The results in Table 1 show that seven out of the 27 statements with percentages of agreement above $70.0 \%$ were ranked as the top factors that contribute to the students' lack of interest in school science with respect to the spread about the calculated mean score for each factor. This is because $88.8 \%$ of the students with a high mean of $3.4(\mathrm{SD}=0.7, \mathrm{n}=247)$ agreed that one of the factors that contribute to the students' lack of interest in science is that "Science demands a lot of students' time of learning to perform better". The next factor where $85.3 \%$ of the students with a high mean $3.4(\mathrm{SD}=0.7, \mathrm{n}=247)$ agreed that it contributed to the students' lack of interest in school science was "If teaching and learning of science could be more practical than it is now, I would have studied science". "If I will be given an automatic admission to any tertiary institution when I passed all subjects with a larger aggregate" and "the content of science is too broad" were also ranked as some of the top factors that contribute to the students' lack of interest in school science as an overall $80.7 \%$ of the students with a high mean of 3.3 $(\mathrm{SD}=0.7, \mathrm{n}=240)$ and $82.3 \%$ of the students with high mean of $3.3(\mathrm{SD}=0.8, \mathrm{n}=248)$ respectively agreed to these statements. From Table $1,72.2 \%$ of the students with a high mean of 3.2 ( $\mathrm{SD}=0.9, \mathrm{n}=244)$ agreed to the statement that "I will study science if I will be sponsored to study science to the university level" was one of the factors that contribute to the students' lack of interest in school science. "Science is difficult to learn in comparison with other subjects" was also indicated as one of the top factors that affected the students' interest in school science as $74.2 \%$ of the students with a high mean of $3.0(\mathrm{SD}=1.0, \mathrm{n}=244)$ agreed to this statement. The last top factor as seen in Table 1 that was agreed upon by $72.9 \%$ of the students with a high mean of $3.1(\mathrm{SD}=1.1, \mathrm{n}=253$ ) but could not be a contributing factor to the students' lack of interest in school science was that the students agreed that their lack of interest in science was not due to the availability of laboratories and materials necessary for the study of science.

From Table 1, 12 other factors with means ranging from 2.9 to 2.6 were also ranked as factors that contribute to students' lack of interest in school science in the table. The results in Table 1 show that $66.8 \%$ and $64.5 \%$ of the students with an equal mean of $2.9(\mathrm{SD}=0.9, \mathrm{n}=$ 239) respectively agreed to the statements that "I see science as a transmission of knowledge from teacher or textbook to the students" and "Science topics are complex and controversial to study" contributed to the students' lack of interest in school science. "I will study science if I will be guaranteed job with higher salaries" was the next factor that $62.5 \%$ of the students with the mean of $2.9(\mathrm{SD}=1.0, \mathrm{n}=242)$ agreed that their interest in science was influenced by such a statement and $61.8 \%$ of the students with the mean of $2.9(\mathrm{SD}=1.0, \mathrm{n}=238)$ agreed that the students' lack of interest in school science was influenced by their weak performance in mathematics. The next factor which $61.0 \%$ of the students with the mean of $2.8(\mathrm{SD}=0.9$, $\mathrm{n}=242$ ) agreed to that influenced their interest was that "I would have studied science if my science teachers encouraged me to". This is followed by the factor that "My lack of interest in science was due to the fact that I used to score low marks in science" which was agreed upon by $58.6 \%$ of the students with the mean of $2.8(\mathrm{SD}=0.9, \mathrm{n}=236)$, and $58.3 \%$ of the students with an equal mean of $2.8(\mathrm{SD}=1.0, \mathrm{n}=236)$ agreed to the statement that "I will study science if I will meet my future career aspirations" contributed to the students' lack of interest in school science. "I would have studied science if science is promoted like sports or politics in Ghanaian mass media (for example, FM/TV)" was the next factor that $53.3 \%$ of the students with the mean of $2.7(\mathrm{SD}=1.0, \mathrm{n}=237)$ agreed upon as contributed to students' lack of interest in school science, and $51.7 \%$ of the students with the mean of $2.7(\mathrm{SD}=1.0, \mathrm{n}=241$ ) agreed to the statement that "Science students most at times fail to quality for university education" was the next factor that contributed to students' lack of interest in school science. The last three factors that contributed to the students' lack of interest in school science were "I would have 
studied science if my parents/guardian encouraged me to study science" which was agreed upon by $51.0 \%$ of the students with the mean of $2.7(\mathrm{SD}=1.0, \mathrm{n}=223)$, "In Ghana most science students end up becoming teachers" which was agreed upon by $51.0 \%$ of the students with the mean of $2.6(\mathrm{SD}=1.0, \mathrm{n}=236)$, and "Our class size is large and that science cannot be studied effectively in such a class" which was agreed upon by $45.6 \%$ of the students with the mean of $2.6(\mathrm{SD}=1.0, \mathrm{n}=238)$.

The results in Table 1 further show that nine of the factors were disagreed upon by the students as factors that could have contributed to the non-science students' lack of interest in school science. For the first factor that was disagreed upon, 49.8\% of the students with the mean of $2.4(\mathrm{SD}=1.0, \mathrm{n}=237)$ indicated that "I would have studied science if my local language was used in teaching it" did not contribute to the students' lack of interest in school science. The next factor that $55.2 \%$ of the students with the mean of $2.3(\mathrm{SD}=1.0, \mathrm{~N}=229)$ disagreed as a factor that contributed to their interest in science was the statement that "I would have studied science if people from my community made it to the top in science", and 59.4\% of the students with the mean of $2.2(\mathrm{SD}=1.0, \mathrm{n}=231)$ disagree that "I would have studied science if Physics and Chemistry were made elective subjects for all students at the third year of the four-year secondary education" contributed their lack of interest in school science. From Table 1, the results further show that $64.9 \%$ of the students with the mean of $2.1(\mathrm{SD}=1.0, \mathrm{n}=$ $243)$ and $65.6 \%$ of the students with a mean of $2.0(\mathrm{SD}=0.9, \mathrm{n}=229)$ disagreed respectively to the statements that "I see science as content of knowledge that is irrelevant and boring to our lives" and "I would have studied science if my voice was heard and valued in science lessons" contributed to their lack of interest in school science. The last three factors which were disagreed upon as factors that contributed to the non-science students' lack of interest in school science were "The subject science is for intellectually gifted students", which was disagreed upon by $72.9 \%$ of the students with the mean of $1.9(\mathrm{SD}=0.9, \mathrm{n}=243)$; "I would have studied science if the topics are attracted to the girls", which was disagreed upon by $82.3 \%$ of the students with the mean of $1.7(\mathrm{SD}=0.8, \mathrm{n}=247)$; and "I would have studied science if my closest friend also studied science, which was disagreed upon by an overall $88.1 \%$ of the students with the mean of $1.6(\mathrm{SD}=0.8, \mathrm{n}=250)$.

The findings from Table 1 show that the school science as a subject that demands a lot of students' time of learning to perform better and less practical nature of science teaching and learning were the most considered factors that contribute to the non-science students' lack of interest in school science. However, the influence of a closest friend on the students' choice of studying school science was considered as the weakest factor among the 27 factors for contributing to the non-science students' lack of interest in school science. The findings from Table 1 further show that the most ranked factor as a contributor to students' lack of interest in school science is a performance related, which is science demands a lot of students' time of learning to perform better. This goes with four other performance-related factors: science as a difficult subject to learn; students' weak performance in Mathematics; and School Science; and science students' failure to quality for university education. The second most ranked factor is content and pedagogical related, which is currently less practical nature of science teaching and learning. The other content and pedagogical factors which contribute to the non-science students' lack of interest in school science include the broad nature of the school science content; teaching and learning of science is a transmission of knowledge from teachers or textbooks to students; science topics are complex and controversial to study; large class size which affect effective teaching of science. One of the support factors which is ranked as the third is the lack of possible access of science students to enter tertiary institutions with larger aggregate. The other support factor is the lack of possible sponsorship package to study school science to the university level.

From Table 1 the findings show that three future prospects as well as three social factors are among the least ranked factors that contribute to the non-science students' lack of interest in school science. The factors that are future prospect-related are lack of the possibility of sci-

\author{
PROBLEMS \\ OF EDUCATION \\ IN THE $21^{\text {st }}$ CENTURY \\ Volume 53, 2013 \\ 15
}


Kenneth ADU-GYAMFI. Lack of Interest in School Science among Non-science Students at the Senior High School Level

PROBLEMS

OF EDUCATION

IN THE $21^{\text {st }}$ CENTURY Volume 53,2013

ence students having guaranteed jobs with higher salaries; the lack of the possibility of science students meeting their career aspirations; and the possibility of science students ending up as teachers. The social factors are lack of encouragement from science teachers; lack of promotion of school science in Ghanaian mass media as it is for sports or politics; and lack of encouragement from parents/guardian for their wards to study school science.

\section{Difference in Male and female Non-science Student'Lack of Interest in School Science}

Research question 2 sought to find out whether the non-science male and female students involved in the study shared equally the factors that contribute to their lack of interest in school science or not. The results on the differences between male and female students' lack of interest in school science are presented in Figure 1.

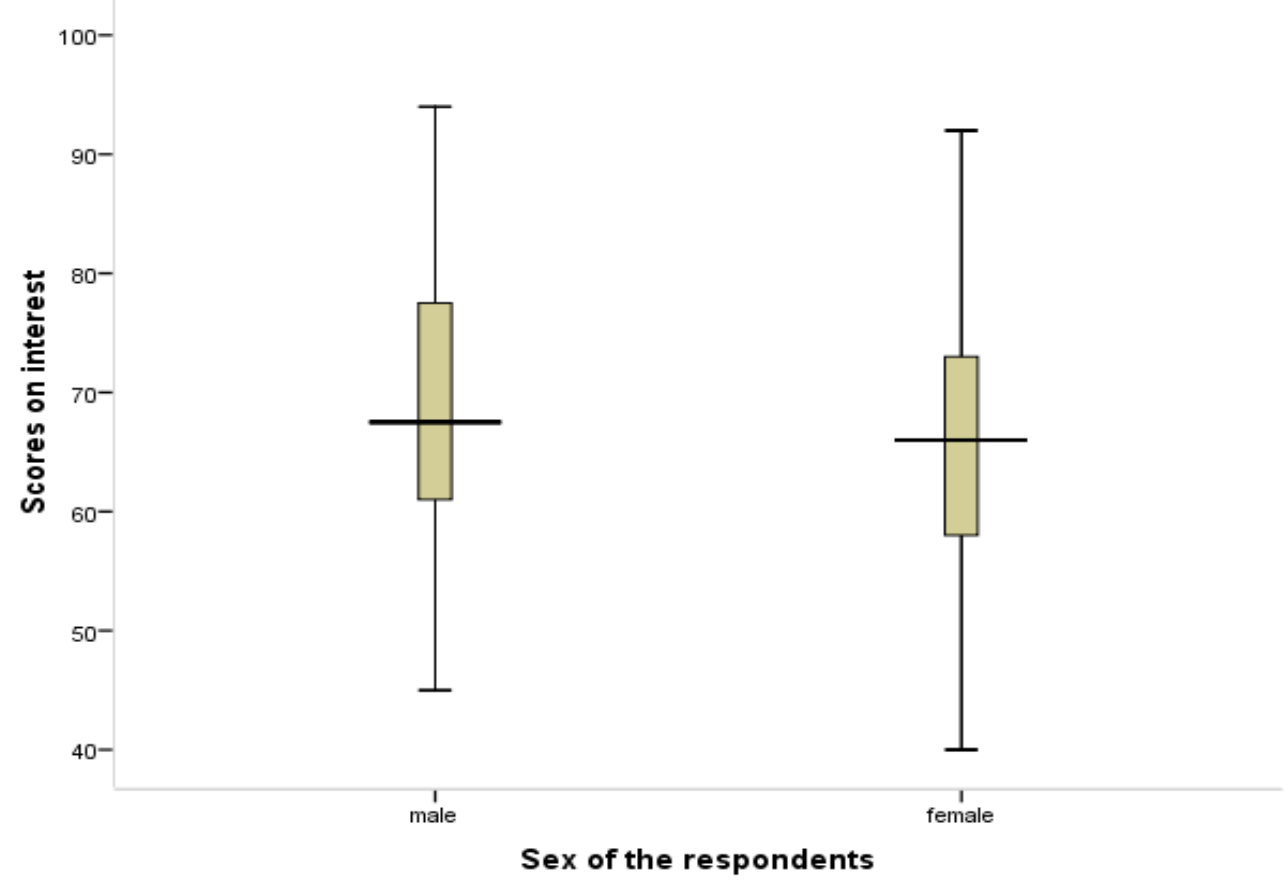

Figure 1: Boxplots of male and female students' lack of interest in school science.

From Figure 1, the median score respectively for the two boxplots of male and female non-science students were seen as 67.5 and 66.0 and the interquartile range for the distribution of the male students was 17.0 and that of their female counterparts was 15.0. With these interquartile ranges, it could be said that the middle $50.0 \%$ of the distribution of scores for the male students was higher to that of the female students. These differences in the interquartile ranges and the median of the distribution could seem that the scores for the factors that contribute to the female non-science students' lack of interest in school science differs from that of their male counterparts.

Though, from the results in Figure 1, the boxplots overlap and that the difference could be said to be a matter of chance but the standard deviations $(\mathrm{M}=68.5, \mathrm{SD}=11.0)$ and $(\mathrm{M}=$ $65.5, \mathrm{SD}=11.2)$ respectively calculated for the distributions of the male and female students give indication that the individual scores within the male and the female were relatively equally spread and that there were not too much extreme cases in the scores on the students' lack of interest. The large standard deviations calculated for the two groups could be due to the sample size used for the study. To find out whether the difference in the means was not by chance but 
statistically significant, the independent-samples t-test analysis was ran at a significance level of 0.05 . The results of the independent-samples t-test analysis are presented in Table 2 .

Table 2. Independent-Samples t-test Results of the Lack of Interest in School Science for Male and Female Non-Science Students.

\begin{tabular}{lllllll}
\hline Sex & $\mathbf{N}$ & $\mathbf{M}$ & SD & t & df & p \\
\hline Male & 116 & 68.5 & 11.0 & 2.1 & 257 & 0.03 \\
Female & 143 & 65.5 & 11.2 & & & \\
\hline
\end{tabular}

The results in Table 2 show that there was statistical significant difference between the scores on male and female non-science students' lack of interest in school science. The mean score for the male non-science students' $(\mathrm{M}=68.5, \mathrm{SD}=11.0)$ lack of interest in school science was statistically significantly different from the mean score for the female non-science students $(\mathrm{M}=65.5, \mathrm{SD}=11.2, \mathrm{t}(257)=2.1, \mathrm{p}=0.03)$ with relatively small effect size $(\mathrm{d}=0.3)$. The findings from Table 2 show that the male non-science students show strong lack of interest in science as compare to the female non-science student.

With the effect size being relatively small, the difference between the male and female non-science students' lack of interest in school science was then considered in terms of the five aspects of the questionnaire. Table 3 presents the results the independent-samples t-test analysis on the five areas.

Table 3. Independent-Samples t-test Results of the Male and Female Non-science Students' Lack of Interest in School Science in Five Areas.

\begin{tabular}{llllllll}
\hline Area & Sex & N & M & SD & t & df & $\mathbf{p}$ \\
\hline Social & Male & 116 & 2.2 & 0.7 & 0.6 & 257 & 0.577 \\
\multirow{2}{*}{ Support } & Female & 143 & 2.2 & 0.7 & & & \\
\multirow{2}{*}{ Future Prospects } & Male & 116 & 3.1 & 0.8 & 2.7 & 257 & 0.008 \\
& Female & 143 & 2.9 & 0.8 & & & \\
Content and Pedagogy & Male & 116 & 2.6 & 0.8 & 1.0 & 257 & 0.335 \\
\multirow{2}{*}{ Performance } & Female & 143 & 2.5 & 0.8 & & & \\
& Male & 116 & 2.4 & 0.4 & 2.1 & 257 & 0.034 \\
& Female & 143 & 2.3 & 0.4 & & & \multirow{2}{*}{0.087} \\
\hline
\end{tabular}

From Table 3, the results show that there was no statistical significant difference between means of male $(\mathrm{M}=2.2, \mathrm{SD}=0.7)$ and female students $(\mathrm{M}=2.2, \mathrm{SD}=0.2, \mathrm{t}(257)=0.6, \mathrm{p}=$ $0.577)$ on the factors that were social related; male $(\mathrm{M}=2.6, \mathrm{SD}=0.8)$ and female students $(\mathrm{M}$ $=2.5, \mathrm{SD}=0.8, \mathrm{t}(257)=1.0, \mathrm{p}=0.335)$ on the factors related to future prospects; and male $(\mathrm{M}$ $=2.9, \mathrm{SD}=0.7)$ and female students $(\mathrm{M}=2.7, \mathrm{SD}=0.7, \mathrm{t}(257)=1.7, \mathrm{p}=0.087)$ on the factors which were performance related. However, there was significant difference between the means of the male $(\mathrm{M}=3.1, \mathrm{SD}=0.8)$ and the female students $(\mathrm{M}=2.9, \mathrm{SD}=0.8, \mathrm{t}(257)=2.7, \mathrm{p}=$ $0.008)$ on the support-related factors; and the male $(\mathrm{M}=2.4, \mathrm{SD}=0.4)$ and female students $(\mathrm{M}=2.3, \mathrm{SD}=0.4, \mathrm{t}(257)=2.1, \mathrm{p}=0.034)$ on the performance-related factors. The findings from Table 3 show that the marginal statistical difference between male and female non-science students' lack of interest in school science was due to the differences in the means of the male and female students in the areas of support and performance related factors, which contributed to the students' lack of interest in school science. 


\section{PROBLEMS \\ OF EDUCATION \\ IN THE $21^{\text {st }}$ CENTURY \\ Volume 53,2013 \\ 18 \\ Discussion}

From the findings of the study, one of the factors that contribute to students' lack of interest in school science is the high demands of students' time for the learning of school science. This may be related to the too broad content nature of school science where there is a lot to learn at any level of study of science (Christidou, 2011). Thus, science students spend most of their academic time concentrating on the learning of scientific concepts and principles and making them seemingly busy on the campus of these schools and colleges in relation other students. It is therefore recommended as in the case of Christidou (2011) that the school science curriculum should be restructured by reducing the workload to enhance the interest of students in school science.

Teaching science through practical activities could be said to be the ideal way of science teaching and learning at the SHS level. Therefore the absence of practical science lessons as agreed by the students could make scientific concepts and principles look abstract and unattractive to students. The non-science students therefore indicated that the students' lack of interest in school science could be attributed to the absence of science practical lessons. The absence of science practical lessons could also be due the too broad content nature of the science curriculum which calls for extra time to complete and such an extra time is difficult to find in our current curriculum.

In Ghana, admission to pursue courses in tertiary institution is course for concern as tertiary institutions which are government-assisted are very few with few places for fresh students. Hence, admission to tertiary institution is very competitive and that students who qualify with larger aggregates are barely selected. Thus, it could be that the non-science students involved in the study have observed that over the years science students from their respectively schools usually qualify with larger aggregate and therefore find it difficult to secure admission to any tertiary institution compared to their counterparts from the other fields of study. This confirms the findings of Fensham (2006).

One of the findings from the study on the factors that contribute to students' lack of interest in school science is lack of sponsorship packages for science students to pursue science from high school through to the university. The call for sponsorship package for science students could be attributed to the fact that science materials which are perceived as expensive and some science related courses take a number of years for a student to graduate compared to other fields of study.

With respect to factors that are performance related, the non-science students attributed their lack of interest in school science to the difficult nature of school science as compared to other subjects and this is what other research works in science education such as Osborne and Collins (2001) have also identified over the years prior to this current study. The current study did not identify the specific difficulties and therefore encourage science educators to conduct studies into those scientific concepts that seem difficult to students to come out with the nature and possible solutions to such difficulties.

Another finding of the study shows that the students' lack of interest in school science is as a result of the teaching of science which was seen as transmission of knowledge from science teachers or science textbooks to students. This confirms Semala (2010) assertion that the methods of teaching science are seen as a tool for whipping the interest of students in school science when carefully selected. Science as a transmission of knowledge from teachers or science textbooks to students could be attributed to the absence of practical science lessons which the students perceive as a factor that contributes to their lack of interest in school science.

From the findings of the study, one of the factors that contribute to students' lack of interest in school science is lack of guaranteed job with higher salaries for science graduates. The non-science students involved in the study perception of lack of jobs for science graduates could be real as Fensham (2006) revealed that there are more job opportunities for graduates of the fields of study which are not science related than the science graduates. Hence, let govern- 
ments and non-governmental organisations (NGOs) who are interested in science education provide students and the public as a whole with information on job opportunities for science students as this could be one of the ways forward to increase the interest of students in school science (OECD, 2006).

The study has shown that another factor that contributes to the students' lack of interest in school science is students' weak performance in Mathematics and Science itself as a subject. Knowledge of Mathematics plays a vital role in learning school science especially in the areas of Chemistry and Physics, and students who are found to perform poorly in Mathematics usually are found wanting when it comes to school science. Hence, Wells et al (n.d.) revealed that students with creditable performance in Mathematics turn to have interest in school science. Therefore the non-science students who appreciate that they show weak performance in Mathematics will obviously show no or little interest in school science. The Science and Mathematics teachers should therefore work hand-in-hand to improve on the performance of students in Mathematics and thereby encouraging students to have interest in school science.

The students perceive that when they study school science they may not meet their career aspiration and therefore show no interest in school science. However, Fensham (2006) indicated that there are more careers under science compared to other fields of study. This means that students are not aware of such careers under science. Could it therefore be said that science has a marketing problem (Osborne \& Collins, 2001)?

The finding that science is not promoted like sports or politics in Ghanaian mass media such as FM/radio stations contribute to the students' lack of interest in school science confirms the findings of Osborne and Collins (2011) where Lucy's interest in school science was once influenced by the continuous discussion of scientific issues on the TV. Hence, promotion of science as an interesting and attractive subject/course to study in the print or electron media could help develop students' interest in school science (Christidou, 2011).

The failure of science students to qualify for the university education contributes in one way or other to the non-science students' lack of interest in school science. The failure could be the show of weak performance of students in Science, which could have its roots in the perceived difficult nature of school science. This calls for more effort on the part of the science teachers in the high schools to deploy their pedagogical content knowledge to assist science students to perform very well to qualify for university education.

The findings from the study have shown that two of the factors that contribute to students' lack of interest in school science are teachers and parents/guardian inability to encourage students to study science. Could this be that the science teachers themselves or the parents of the students do not have interest in school science and therefore cannot encourage their students to pursue subjects and courses that are science related? Hence, the science teachers who had once taught these students could not have been role models to the students, and role model is said to be an interpersonal factor that influences a lot when it comes to students' course and career choices (Ocansey, 2009).

The study has shown that the factors that contribute to the students' lack of interest in school science include the broad content and complex and controversial nature of school science. The nature of science content as too broad is a fact that science educators cannot run away from. This is because there are many scientific concepts to be learned at any stage of the educational ladder and that is why the non-science students' perception seems to be true. The controversial and complex nature of school science could be that the students seem not to be in agreement with how teachers explain scientific concepts in relation to the real world.

In Ghana, the issue of larger class size is something that has come to stay. Moreover, now that the leaders of the country are thinking of introducing free education from the basic school through to the SHS level, the class size will continue to increase when the policy is implemented. Hence, the larger class size management should be an issue to be considered by the Ghana Education Service (GES). It is therefore recommended that seminars and workshops on managing larger class size for effective teaching and learning of school science should be 
PROBLEMS

OF EDUCATION

IN THE $21^{\text {st }}$ CENTURY Volume 53,2013

20

organised for science teachers at the SHS level to help them acquire the skills needed for managing larger class size effectively and efficiently.

A statistical significant difference in the students' lack of interest between male and female non-science students with which the mean score of the male students is higher than that of the female mean score shows that the science subject which was once liked by male students could be losing its attractiveness to female students. Hence, Ghana should take heed to the wake-up call by the U. S. (Wells, Sanchez, and Attridge, n.d.) to take measures necessary to help provide an expanding and talented pool of graduates of science education.

\section{Conclusions}

The study has shown that the non-science students' lack of interest in school science is attributed to factors such as higher demands of students' time in learning science, less practical nature of science teaching and learning, failure of science students with larger aggregate from SHS to gain admission into tertiary institutions, too broad nature of science content, lack of sponsorship for science students, school science as difficult subject compared to others, and teaching of science is a transmission of knowledge from science teachers or textbooks to students. The other factors are complex and controversial nature of science topics, lack of guaranteed jobs with higher salaries for science graduates, students' weak performance in Mathematics and Science, lack of encouragement from science teachers and parents/guardians, lack of possibility of meeting one's career, lack of promotion for science in the Ghanaian mass media, failure of science students to qualify for university education, and large class size.

The study has also shown that there was statistical significant difference between nonscience male and female students' lack of interest in school science with the male students showing higher lack of interest in school science. The Ministry of Education and the GES should adopt policies that will retain male students in their usual pursuit of science education and to attract female students to various fields of science education as well. Science teachers are therefore encouraged to adopt strategies that could encourage students to develop and show interest in science related subjects and courses.

\section{References}

Christidou, V. (2006). Greek students's science-related interests and experiences: Gender differences and corrections. International Journal of Science Education, 28, 1181-1199.

Christidou, V. (2011). Interest, attitudes, and images related to science: Combining students' voices with the voice of school science, teachers, and popular science. International Journal of Environmental Science Education, 6 (2), 141-158.

Cohen, L., Manion, L., \& Morrison, K. (2005). Research methods in education (5 $5^{\text {th }}$ Ed.). London: Taylor \& Francis e-Library.

Creswell, J. W. (1994). Research design: Qualitative and quantitative approach. California: SAGE Publications, Inc.

Fensham, P. J. (2006). Student interest in science: The problem, possible solutions, and constraints. Retrieved October 15, 2011, from http://www.acer.edu.au/documents/RC2006_Fensham.pdf

Hidi, S., \& Renninger, K. A. (2006). The four-phase model of interest development. Educational Psychology, 41 (2), 111-127.

Mensah, F. (2007). Gender and developmental differences in attitudes toward science between secondary school year one students and year three students. Gender and Behaviour, 5 (2), 1240-1247.

Ministry of Education, Youth, and Sports [MEYS]. (2004). White paper on the report of the education reform review committee. Accra: MEYS.

Ocansey, F. (2009). The influence of interpersonal factors on secondary school students' career aspirations in Ghana. Ghana Journal of Education: Issues and Practices, 1 (1), 72-84.

Organisation for Economic Co-operation and Development [OECD]. (2006). Global Science Forum: Evolution of student interest in science and technology studies policy report. Retrieved October 8 , 2011, from http://www.oecd.org/dataoecd/16/30/36645825.pdf 
Organisation for Economic Co-operation and Development [OECD]. (2008). Science and technology policy: Encouraging students' interest in science and technology studies. Retrieved March 13, 2013, from www.oecd.org/sti/sci-tech/encouragingstudent interestinscienceandtechnologystudies.htm

Osborne, J., \& Collins, S. (2001). Pupils' views of the role and value of the science curriculum: A focusgroup study. International Journal of Science Education, 23 (5), 441-467.

Pallant, J. (2005). SPSS survival manual: A step by step guide to data analysis using SPSS version 12. Maidenhead: Open University Press.

Renninger, K. A., \& Hidi, S. (2011). Revisiting the conceptualisation, measurement, and generation of interest. Educational Psychologist, 46 (3), 168-184.

Semala, T. (2010). Who is joining physics and why? Factors influencing the choices of physics among Ethiopian university students. International Journal of Environmental and Science Education, 5, 319-340.

Thoman, D. B., Sansone, C., Fraughton, T., \& Pasupathi, M. (2012). How students socially evaluate interest: Peer responsiveness influences evaluation and maintenance of interest. Contemporary Educational Psychology. Retrieved January 08, 2013, from www.csulb.edu/ dthoman/Pubs/ Tho manSansoneFraughton\&Pasupathi2012.pdf

Wells, B. H., Sanchez, H. A., \& Attridge, J. M. (n.d.). Modeling student interest in science, technology, engineering, and mathematics. Waltham, MA: Raytheon Company.

Advised by Judita Stankute, SMC “Scientia Educologica”, Lithuania

Received: March 18, 2013

Accepted: April 05, 2013

Kenneth Adu-Gyamfi

M. Phil., Head of Department of Science Education, Mampong Technical College of Education, P. O. Box 31, Mampong-Ashanti, Ghana.

E-mail: dondonsinco@yahoo.com 